\title{
ASHLEIGH BENNETT
}

\section{Rethinking Electoral Reform Processes after the Report of the Electoral Commission on the Review of the MMP Voting System}

Submitted for the LLB (Honours) Degree

Faculty of Law

Victoria University of Wellington

2013 


\title{
Contents
}

\begin{tabular}{|c|c|c|c|}
\hline I & \multicolumn{3}{|c|}{ Introduction } \\
\hline II & & \multicolumn{2}{|c|}{ The Electoral Commission's Report } \\
\hline & A & \multicolumn{2}{|c|}{ The Review } \\
\hline & $\mathrm{B}$ & \multicolumn{2}{|c|}{ The Recommendations } \\
\hline III & & \multicolumn{2}{|c|}{ The Response from the Government and Parliament } \\
\hline & A & \multicolumn{2}{|c|}{ The Response } \\
\hline & $\mathrm{B}$ & \multicolumn{2}{|c|}{ Consensus and Electoral Rules } \\
\hline IV & & \multicolumn{2}{|c|}{ The Constitutional Implications } \\
\hline & A & \multicolumn{2}{|c|}{ The Issue } \\
\hline & $\mathrm{B}$ & \multicolumn{2}{|c|}{ Partisan self interest } \\
\hline & & & The party vote threshold \\
\hline & & (b) & The one electorate seat exception \\
\hline & $\mathrm{C}$ & \multicolumn{2}{|c|}{ Undermining the Democratic Process } \\
\hline & $\mathrm{D}$ & \multicolumn{2}{|c|}{ Democratic Legitimacy and the Democratic Deficit } \\
\hline & $\mathrm{E}$ & \multicolumn{2}{|c|}{ Finding a Solution } \\
\hline & & (a) & Introducing 'deliberative' processes \\
\hline & & & Citizens' Assemblies on Electoral Reform \\
\hline & & & Introducing a 'citizen initiated' mechanism \\
\hline $\mathrm{V}$ & & \multicolumn{2}{|c|}{ Conclusion } \\
\hline VI & & \multicolumn{2}{|c|}{ Bibliography } \\
\hline
\end{tabular}

\begin{abstract}
The 2012 Report of the Electoral Commission on the Review of the MMP system recommended that several changes be made to the way in which future parliaments are elected in New Zealand. The lack of legislative response to the recommendations highlighted an issue inherent in New Zealand's constitutional arrangements - that changes to electoral rules are designed and enacted by politicians, and there is no mechanism through which citizens can initiate or meaningfully engage with electoral reform processes. This paper looks at whether there is a better way that such proposals for electoral rule changes could be managed, proposing the use of 'citizen initiated' Citizens' Assemblies on Electoral Reform.
\end{abstract}

\section{Key Words}

Constitution, Electoral Reform, Citizens' Assembly, Deliberative Democracy, Citizen Initiated 


\section{Introduction}

This report is about our democracy. It is about the way New Zealanders give their consent to the exercise by Parliament and the Government of great public power.

- The Royal Commission on Electoral Systems, $1986^{1}$

The way in which elections operate "has inevitable consequences for the composition, powers and policy priorities of government.", Because of those consequences, issues arising around the electoral system are of foremost significance to New Zealand's constitution.

The current New Zealand electoral system, known as Mixed Member Proportional Representation (MMP), was introduced through public referendum in 1993 . $^{3}$ Since that time there has been significant debate about the merits of the system. As a part of its election platform in 2008, the National Party pledged to hold a referendum, asking the public whether the MMP system should be retained or should be replaced with another option. ${ }^{4}$ A part of the enabling legislation required that, should more than 50 percent of electors choose to retain MMP, the Electoral Commission "must commence a review of the Mixed Member Proportional representation voting system ... as soon as practicable". 5 At the 2011 election, 57.8 percent of voters in the electoral referendum voted to retain MMP ${ }^{6}$ thus launching a significant independent review of MMP. The review looked at five issues set out in the Electoral Reform Act $2010 .^{7}$

In November 2012, the Electoral Commission released its final report, which recommended several changes to the MMP system. ${ }^{8}$ In May 2013 the Government of the day announced that none of the recommended changes would be adopted because "there is absolutely no consensus ... across parliament" on the form that the improved MMP system should take. 9

\footnotetext{
${ }^{1}$ The Royal Commission on the Electoral System Towards a Better Democracy (Government Printer, December 1986) at [1.1].

${ }^{2}$ Raymond Miller NZ Government and Politics (5th ed., Oxford University Press, Melbourne, 2009) at 169.

${ }^{3}$ At 38 .

${ }^{4}$ At 168

${ }^{5}$ Electoral Referendum Act 2010, s 75.

${ }^{6}$ Electoral Commission Report of the Electoral Commission on the Review of the MMP Voting System (E9, 29 October 2012) at 6.

${ }^{7}$ Electoral Referendum Act 2010, s 76.

${ }^{8}$ Electoral Commission, above n 6, at 5.

9 Judith Collins "MMP Changes Impossible Without Agreement" 15 May 2013 Beehive

$<$ http://www.beehive.govt.nz $>$.
} 
The lack of legislative response to the Electoral Commission's report highlights an inherent constitutional problem. Under the current constitutional arrangements, neither the Government nor Parliament were legally obliged to take any action in response to the recommendations. In all situations, reform of electoral rules and processes are left in the hands of those who are elected by the rules and processes in question. Under this arrangement, politicians are heavily involved in both the design and implementation of any changes to electoral rules. This research paper explores this problem in light of the changes recommended by the Electoral Commission. Through examination of the nature of the recommendations, and the impact the changes could have on each of New Zealand's main political parties, it is clear that partisan self interest has coloured the responses from across Parliament.

Ultimately, this paper asks whether there is a better way that such proposals for electoral rule changes could be managed. In short, I conclude that a sea change is required to address the problematic nature of New Zealand's electoral reform processes. Drawing on the discussions of constitutional lawyers and theorists in New Zealand and around the world on electoral reform processes, democratic engagement, and democratic legitimacy, the solution proposed here is to engage 'citizens' assemblies' on electoral reform - as has been done with some success in Canada and the Netherlands - including a mechanism that allows such an assembly to be 'citizen initiated'.

\section{The Electoral Commission's Report}

A The Review

The Electoral Commission's review was an independent inquiry into whether changes to the MMP voting system were necessary or desirable. ${ }^{10}$ It was conducted by the Electoral Commission, whose role includes considering and reporting "on electoral matters referred to it by the Minister of Justice or House of Representatives" and making "any recommendations for changes to the system to the Minister of Justice". ${ }^{11}$ The Commission, led by Sir Hugh Williams, Jane Huria and Robert Peden, carried out the review with the help of a number of expert submissions, and with around 6000 public submissions across two rounds of public

\footnotetext{
${ }^{10}$ Electoral Commission, above n 6, at 2.

${ }^{11}$ Electoral Referendum Act 2010, ss 75(2)(a) and 75(2)(b).
} 
consultation. ${ }^{12}$ This extensive consultation firstl gave members of the public the chance to answer open-ended questions about how MMP should look, and then gave them a further chance to comment specifically on proposed recommendations in the months leading up to the report being finalised. ${ }^{13}$ The review was a significant project for the Electoral Commission. The process was lengthy, conducted over almost a year, and cost the taxpayer around 1.3 million dollars. ${ }^{14}$

As outlined in the final report, the independent review of the MMP system looked primarily at four main issues: ${ }^{15}$

1. The thresholds for gaining entry into Parliament, which are currently set at either 5 percent of the party vote, or one electorate seat;

2. The ratio of electorate to list seats in Parliament, and the effect that this has on proportionality;

3. Dual candidacy, where those seeking election can do so by both contesting an electorate and being on a party list; and

4. The order of candidates on party lists, and whether the lists should be open or closed.

The Commission also had scope within the legislation to look at "any other issues referred to the Commissioner by the Minister of Justice or Parliament", but no other matters were referred during the process. ${ }^{16}$

\section{B The Recommendations}

The Electoral Commission's report recommended that the five percent party vote threshold should be lowered to four percent (and should be reviewed every three elections), and the one electorate seat threshold should be abolished. ${ }^{17}$ It also expressed some concern about the representativeness and proportionality of parliament, recommending that a 60:40 ratio of

\footnotetext{
${ }^{12}$ Electoral Commission, above n 6, at 7.

${ }^{13}$ See generally Andrew Geddis "Stop Wasting our Time" (14 May 2013) Pundit <http://pundit.co.nz>; Electoral Commission, above $\mathrm{n} 6$, at 7.

${ }^{14}$ Electoral Commission, above $\mathrm{n} 6$, at 7.

${ }^{15}$ At 6

${ }^{16}$ At 6

${ }^{17}$ Electoral Referendum Act 2010, s 76(f).
} 
electorate to list seats would be the optimum level to maintain a diverse, representative and proportionate parliament. ${ }^{18}$

The report envisaged that, should Parliament agree with the recommendations, the proposed changes would be enacted in time to be in place for the 2014 general election. ${ }^{19}$ It didn't consider that the changes would "fundamentally alter" the voting system, so further envisaged that they could be passed through parliament without a referendum. ${ }^{20}$

\section{The Response from the Government and Parliament}

\section{AThe Response}

As previously outlined, the Government announced that the changes recommended by the Electoral Commission could not be implemented, as there was no consensus across Parliament. $^{21}$ According to that announcement, Labour and the Greens would be the only parties in the House prepared to support the package of recommendations as a whole. ${ }^{22}$ National, the Māori Party and ACT all support retaining the status quo. ${ }^{23}$ The other parties in the House - Mana, United Future and NZ First - would support some of the recommendations, but not others. ${ }^{24}$ The government announcement used this information to demonstrate the breadth of political opinion on the changes proposed.

\section{BConsensus and Electoral Rules}

Whether or not such a consensus across Parliament is required for making changes to electoral rules and processes is a question that lacks a clear answer. General agreement across the House of Representatives has been seen on a number of important constitutional and electoral issues - one example being the vote to introduce the Constitution Act 1986, which was supported by both the Labour and National parties - but certainly has not been evidenced for all changes to constitutional and electoral rules in recent political history.

\footnotetext{
${ }^{18}$ Electoral Commission, above n 6, at 6.

${ }^{19}$ At 10

${ }^{20}$ At 10 .

${ }^{21}$ Judith Collins, above $\mathrm{n} 9$.

${ }^{22}$ Judith Collins, above $n 9$.

${ }^{23}$ Judith Collins, above $\mathrm{n} 9$.

${ }^{24}$ Judith Collins, above $n 9$.
} 
Under New Zealand's constitution Parliament enjoys untrammelled sovereignty to pass any law whatsoever. ${ }^{25}$ Legally, there are no limitations on its power to make laws, and the changes could certainly have been passed through the House had the National Party supported the package. It has been suggested, however, that a convention exists that requires consensus for making constitutional changes, including changes to electoral rules. ${ }^{26}$ Conventions are a "non-legal" source of New Zealand's constitution. ${ }^{27}$ They are described as "rules of political obligation that are distinguished from ordinary political usage in two ways: they evoke a sense of obligation that the actors are bound by a rule of conduct, and they serve a necessary constitutional purpose." 28

Sir Ivor Jennings developed a test for determining whether a convention exists. ${ }^{29}$ The first step of that test is to ask whether there are any precedents for such a rule. ${ }^{30}$ The second step is to ask whether the actors in the precedents believed they were bound by the rule. ${ }^{31}$ The third step is to consider whether there is a constitutional reason for the rule. ${ }^{32}$ Thus, determining whether a convention requiring a consensus on constitutional matters exists or is at least developing requires examination of a wide range of past proposals for constitutional, and in this context electoral rule, changes.

A number of important changes to the constitution and electoral rules have been made with consensus, as well as several proposals aborted due to a lack of consensus. Along with the Constitution Act 1986, an example is the Bill of Rights Act 1990. The Act was initially envisaged as entrenched and supreme legislation, ${ }^{33}$ but was passed as ordinary legislation as there was no consensus - across Parliament and across the submissions to the Select Committee - on the entrenchment provision. ${ }^{34}$ Matthew Palmer highlights, however, that other important changes were made without consensus. He writes that there have been a number of changes, some of them quite significant, that "slip through the system... unheralded and unnoticed."35 Examples include the Supreme Court Act 2003, which abolished the right

\footnotetext{
${ }^{25}$ Constitution Act 1986, s 15.

${ }^{26}$ See The Royal Commission on the Electoral System, above $\mathrm{n} 1$ at [7.33].

${ }^{27}$ Joseph PA, Constitutional and Administrative Law in New Zealand (2nd ed, Brookers, 2001) at 34.

${ }^{28}$ At 34

${ }^{29}$ Sir Ivor Jennings The Law and the Constitution $\left(5^{\text {th }}\right.$ ed, University of London Press, 1959) at 136.

${ }^{30}$ At 136.

${ }^{31}$ At 136 .

${ }^{32}$ At 136 .

${ }^{33}$ Geoffrey Palmer "A Bill of Rights for New Zealand: A White Paper" [1984-1985] 1 AJHR A6 at pp 9-16 and 53.

${ }^{34}$ See New Zealand Bill of Rights Act 1990; (21 August 1990) 510 NZPD 3761.

${ }^{35}$ Matthew Palmer "New Zealand Constitutional Culture" (2007) 22 NZULR 565 at 594.
} 
of appeal to the Privy Council. ${ }^{36}$ That Act was passed into law without consensus. ${ }^{37}$ It was pushed through Parliament by Hon Margaret Wilson and the Labour Government, in the face of opposition from the National Party, some minor parties, and across the business and legal communities. $^{38}$

Significant changes to electoral rules have also been made both with and without consensus. Recently, the Electoral (Finance Reform and Advanced Voting) Amendment Act 2010 passed into legislation with 116 'aye' votes - the legislation was virtually unanimously supported across Parliament. ${ }^{39}$ Likewise, the major overhaul of the electoral system in 1993 was implemented through referendum support, rather than an ordinary parliamentary majority, ${ }^{40}$ and the Electoral Referendum Act 2010, which set up the 2011 referendum on the electoral system was passed with unanimous support. ${ }^{41}$ Notably, the parliamentary debates on each of these pieces of legislation were strongly focused on the need for consensus, and celebrated that it had been achieved. Simon Power highlighted that "electoral law should be based on a broad consensus so that the rules are enduring and certain across elections". 42 Conversely, however, other important electoral rule changes have been passed without recourse to a consensus across parliament. The Electoral (Disqualification of Sentenced Prisoners) Amendment Act 2010 was passed by a small majority only days before the Electoral (Finance Reform and Advanced Voting) Amendment Act 2010 and the Electoral Referendum Act $2010{ }^{43}$ Again, consensus was brought up in parliamentary debates, but only by those in opposition to the Bill. ${ }^{44}$ Earlier changes to electoral rules followed the same course, including the Electoral Finance Act 2007, the Electoral (Vacancies) Amendment Act 2004, changes to Māori seats, and amendments to broadcasting and advertising rules. ${ }^{45}$

Applying Jennings' test, there does appear to be some precedents for the rule that consensus is required when making constitutional law changes, including changes to electoral rules, as well as indications from parliamentary debates that the actors considered themselves to be bound by that requirement. However, there exists clear instances where Parliament hasn't

\footnotetext{
${ }^{36}$ (14 October 2003) 612 NZPD 9096.

37 (14 October 2003) 612 NZPD 9096.

${ }^{38}$ Raymond Miller, above n 2, at 93.

39 (15 December 2010) 669 NZPD 16441.

${ }^{40}$ Raymond Miller, above $\mathrm{n} 2$, at 93.

41 (15 December 2010) 669 NZPD 16441; Simon Power "Bill for referendum on voting systems passed unanimously" (15 December 2010) New Zealand Government <http://beehive.govt.nz>.

42 (15 December 2010) 669 NZPD 16441.

43 (8 December 2010) 669 NZPD 15961.

44 (8 December 2010) 669 NZPD 15961.

45 (18 December 2007) 644 NZPD 14038; (1 December 2004) 622 NZPD 17332; Graeme Edgeler "On Consensus" (15 May 2013) Legal Beagle <http://www.publicaddress.net>.
} 
considered itself bound by the precedents, and have made significant changes without consensus.

In light of the fact that legislative history shows that partisan electoral law changes have been made on a number of occasions, the Government's position - that the Electoral Commission's recommendations could not be implemented without consensus - appears somewhat artificial. Despite having passed the enabling legislation, the currently governing National Party, with 59 members in the 121 seat Parliament, is itself opposed to the changes proposed in the 2012 report, and instead supports retaining the status quo. As this is the case, finding a consensus in Parliament would be entirely impossible, when almost half of all MPs would not have supported any changes proposed.

\section{The Constitutional Implications}

AThe Issue

Under New Zealand's constitutional arrangements, the recommendations of the Electoral Commission could legally be ignored. However, in the aftermath of the announcement that no action would be taken, deep dissatisfaction with the decision was widely expressed. ${ }^{46}$ Among others, constitutional lawyer Andrew Geddis and political commentator Vernon Sharp have expressed concern that a review of such a significant and public nature can be rendered "a complete waste of time". 47

This situation gives rise to concern about New Zealand's constitution. Elections are a fundamental part of our elective democracy, but the way in which electoral rules are formed and reformed seems inherently problematic. In a recent political science journal, Janine Hayward highlighted the importance of having a process of electoral reform that operated with integrity, rather than struggles to balance partisan self-interest. ${ }^{48}$ The issue in New Zealand is that such a process does not currently appear to exist in any effective form.

\footnotetext{
${ }^{46}$ See Andrew Geddis, above n 13; Vernon Sharp "MMP Proposals need Referendum” (16 May 2013) Stuff $<$ http://www.stuff.co.nz>; Kate Chapman "Government's MMP review response slammed” (15 May 2013) Stuff Politics < http://www.stuff.co.nz>; Lianne Dalziel "Minister's response to MMP review a travesty (14 May 2013) Labour Party <http://www.labour.org.nz>.

${ }^{47}$ Andrew Geddis, above n 13; see also Vernon Sharp, above n 46.

48 Janine Hayward "Citizens Assemblies and Policy Reform in New Zealand" (2013) 9(2) Policy Quarterly 70 at 71.
} 


\section{BPartisan self interest}

Electoral reform has always been difficult to implement, because the way in which political parties are elected so clearly and directly affects those who make the laws - parliamentarians. Political scientists and constitutional lawyers generally agree that self interest is a key determinant in parties' attitudes to electoral reform. ${ }^{49}$ The conclusion of Bowler et al, in a study that looked at proposals for electoral change in Australia, Germany and the Netherlands as well as in New Zealand, was that, while other factors are at play, "rational self interest is a major feature" in determining political actors attitudes toward electoral change. ${ }^{50}$ Likewise, Pilet and Bol write that the overwhelming academic view is that "parties are first and foremost strategic players which evaluate any change in the electoral system with regard to its impact on the balance of power between and within parties," there is general consensus that parties are driven by "their vested interest". 52 Essentially, in New Zealand as well as around the world, the assumption is that political parties will generally favour the manner of electing parliament that is most likely to favour their chances of success in upcoming elections. In a system such as MMP, where electoral 'success' does not rest only on a specific party's result, but also on the results of other parties, this self interest problem may be amplified. Parties within the system will position themselves in a way that benefits both themselves and potential governing partners, in order to best ensure a positive result come election time.

This self interested approach to electoral reform is problematic because "the laws governing the conduct [of elections] are crucially important" ${ }^{53}$ and allowing self interest to shape the way in which they develop can have implications for the operation of democracy itself. The changes recommended by the Electoral Commission would have effected the make-up of past parliaments, and would also likely impact on upcoming elections. The significant role of self interest of political parties can be demonstrated through analysis of each of the thresholds

\footnotetext{
49 See Shaun Bowler, Todd Donovan, and Jeffrey A. Karp "Why Politicians Like Electoral Institutions: Selfinterest, Values or Ideology?" (2006) 68:2 Journal of Politics 434; Jean-Benoit Pilet \& Damien Bol "Party Preferences and Electoral Reform: How Time in Government Affects the Likelihood of Supporting Electoral Change" (2013) 34/3 West European Politics 568, at 568; Carles Boix "Setting the Rules of the Game: The Choice of Electoral Systems in Advanced Democracies" (1999) 93:3 American Political Science Review 609; and Kenneth Sheppsle "A Comment on Insitutional Change" (2001) 13 Journal of Theoretical Politics 321.

${ }^{50}$ Shaun Bowler et al, above n 49, at 434.

${ }^{51}$ Jean-Benoit Pilet \& Damien Bol, above n 49, at 568.

52 At 569.

53 Alan McRobie "The Electoral System" in Phillip Joseph (ed) Essays on the Constitution (Brookers Ltd, Wellington, 1995).
} 
recommended to be changed. This analysis begins to demonstrate the constitutional problem that the response to the Electoral Commission's review has highlighted. The party vote threshold

The party vote threshold requires parties to reach that threshold before they can gain entry into parliament. Under the status quo, if a party does not reach five percent of the nationwide party vote, they will not be represented in the House at all (except through the one electorate seat exception). The threshold exists to ensure that the House of Representatives is not effected by an "undue proliferation of very small parties in Parliament". 54 It was imported directly from the German system, which also operates with a five percent party vote threshold. ${ }^{55}$ As outlined by the Electoral Commission's Report on MMP, the threshold was designed to balance the main objectives of MMP: (1) proportionality, and (2) effective parliaments and stable government. ${ }^{56}$ The Electoral Commission considered that the five percent threshold currently in place is "higher than it needs to be to strike the right balance" between the two objectives, and thus recommended lowering it to four percent. ${ }^{57}$

A lower party vote threshold of four percent would have effected the make up of parliament in several MMP elections. There have been three instances where parties have commanded between four and five percent of the party vote. ${ }^{58}$ One of these instances was the 2008 Election, in which New Zealand First received $4.1 \%$ of the party vote, and thus did not return to parliament. ${ }^{59}$ In that case, if the threshold had been four percent rather than five they would have been represented in parliament with five MPs.

The party vote threshold only directly effects the minor parties in parliament. National and Labour, and increasingly the Green Party, consistently enjoy support well above five percent, and are thus not faced with the prospect of falling short of any threshold for entry into parliament. Smaller parties currently represented in Parliament on the other hand, do face that prospect. Indirectly, however, the threshold also effects the larger parties, as all MMP elections thus far have resulted in multi-party governing arrangements. According to data collected and released through the Beehive, a lower threshold is supported by the Labour

\footnotetext{
${ }^{54}$ Electoral Commission, above n 6, at 7.

${ }_{55}^{5}$ Bundewahlgesetz (Federal Election Law) 1956 (Germany), Art 6(6).

${ }^{56}$ Electoral Commission, above $\mathrm{n} 6$, at 8 .

${ }^{57}$ Electoral Commission, above $\mathrm{n} 6$, at 8 .

${ }^{58}$ At 8 .

59 "2008 General Election: Results of the Official Count" (22 November 2008) 180 New Zealand Gazette 4638.
} 
Party, the Green Party, the Māori Party, the Mana Party and the United Future Party. ${ }^{60}$ The Labour Party (along with their closely allied Green Party colleagues) would be the most likely to benefit from smaller parties gaining more seats in Parliament as the incumbent Government are themselves polling well and will almost certainly be the largest party in the next parliament, but appear to have few options in terms of governing partners. ${ }^{61}$

Unusually (and in stark contradiction to the ordinary hypothesis regarding self interest and electoral laws), the lowering of the threshold is actually opposed by the party that stands to gain the most from the threshold. The New Zealand First Party support retaining the five percent threshold despite consistently polling around the five percent mark, and thus being at risk of falling below the threshold for entry into parliament, as well as having fallen below at previous elections.

(c) The one electorate seat exception

The one electorate seat exception to the party vote threshold - designed to make it easier for minor parties to gain entry into parliament where their supported is heavily concentrated in an area, region or electorate - was also imported from the German Electoral System. ${ }^{62}$ In Germany, the exception is three electorate seats. ${ }^{63}$ In the context of a much larger population and parliament, the threshold for entry into the Bundestag is designed to allow parties with significant regional support to be represented. ${ }^{64}$ The decision to set the threshold at just one seat in New Zealand was presumably a response to a much smaller parliament, but the aim of the threshold was largely unexplained by the Royal Commission. ${ }^{65}$ In New Zealand, the exception has had quite a significant impact on the makeup of parliaments, and has become increasingly unpopular. ${ }^{66}$ While in Germany the provision operates to make regional voices stronger, in New Zealand it has given rise to "wheeler dealing" and "clever practice" around election times. ${ }^{67}$ Sir John Wallace KNZM QC was a chairman of the 1986 Royal

\footnotetext{
${ }^{60}$ Judith Collins, above n 9.

${ }^{61}$ See Colmar Brunton "Current ONE New Colmar Brunton Poll” (25 Aug 2013) Colmar Brunton New Zealand $<$ http://www.colmarbrunton.co.nz $>$.

${ }^{62}$ Bundewahlgesetz (Federal Election Law) 1956 (Germany), Art 6(6).

${ }^{63}$ Art 6(6).

${ }^{64}$ See The Royal Commission on the Electoral System, above n 1, at [2.116].

${ }^{65}$ Ryan Malone Rebalancing the Constitution: The Challenge of Government Law-Making under MMP (Institute of Policy Studies, Wellington, 2008) at 38.

${ }^{66}$ Electoral Commission, above n 6, at 8.

${ }^{67}$ John Wallace "Reflections on Constitutional and Other Issues Concerning our Electoral System: The Past and the Future" (2002) 33 VUWLR 719, at 735.
} 
Commission that recommended adopting the exception as a part of the MMP package. ${ }^{68}$ After observing the early MMP elections, he notably changed his opinion on the exception upon seeing the way in which it had operated in the New Zealand context: ${ }^{69}$

I now incline to the view that the New Zealand voting public is so unhappy and cynical about political conduct that anything which can have an aura of clever practice is better avoided. I would, therefore, abolish the provision under which the threshold is waived for a party that wins a constituency seat.

Wallace described the operation of the exception as giving rise to arrangements where "Party A withdraws its candidate ... in order to encourage voters who would otherwise have given their electorate vote to Party A to give their vote to Party B". ${ }^{70}$ This type of arrangement has occurred between potential coalition partners, and has been seen to manipulate voter behaviour. Often, voters cast their vote strategically rather than voting for their preferred candidate in their electorate, thus voting for Party B, rather than their first choice, Party A. ${ }^{71}$ Bowler et al write that voters recognise that their vote can influence "the partisan composition of parliament" if their minor party wins an electorate seat and passes the threshold, or wins more electorate seats than its share of the party vote would allocate them. ${ }^{72}$

In terms of the National Party, there is certainly an argument that removing the exception would impact their position going into the 2014 Election. The incumbent Government is led by the National Party, which is represented by 59 Members of Parliament. Its ability to govern is secured by 'Confidence and Supply Agreements' with the single member ACT Party, the three member Māori Party, and the single member United Future Party. ${ }^{73}$ This arrangement is synonymous with the MMP system, under which no party has been able to govern without coalition or support partners. None of these support partners were directly impacted by any threshold or coat-tailing provisions at the 2011 election. Each is represented in Parliament only by the members who won their electorates. However, changes to those rules may impact the positions of National and each of their governing partners looking

\footnotetext{
${ }^{68}$ The Royal Commission on the Electoral System, above n 1, at [2.116].

${ }^{69}$ John Wallace, above n 67, at 736.

${ }^{70}$ John Wallace, above n 67, at 735.

${ }^{71}$ Shaun Bowler et al, above $\mathrm{n} 49$, at 6.

${ }^{72}$ At 6

${ }^{73}$ See generally Confidence and Supply Agreement with Act New Zealand (5 December 2011) New Zealand Parliament <www.parliament.govt.nz>; Relationship Accord and Confidence and Supply Agreement with the Māori Party (11 December 2011) New Zealand Parliament <www.parliament.govt.nz>; Confidence and Support Agreement with United Future New Zealand (5 December 2011), New Zealand Parliament $<$ www.parliament.govt.nz $>$.
} 
forward, especially as it may ultimately discourage voters from voting for the minor parties at all. Without the opportunity to bring other members in at future elections, it is likely that voters would choose to vote for their preferred candidate, thus resulting in significant blows to the ACT Party and the United Future Party. As National's governing parties, such a blow is against the political interests of National, and of ACT and United Future. This is reflected in each party's position on the recommended changes; National, ACT and United Future all support a retention of the status quo. ${ }^{74}$ Likewise, each of the parties in opposition support the abolition of the exception, arguably as a direct consequence of their view that the exception works in the current Government's favour. ${ }^{75}$

The political survival of the ACT Party, whose support has steadily declined over recent elections, is dependant on the one electorate seat threshold. The last election in which the party reached the five percent party vote threshold was $2002 .^{76}$ As previously discussed, in each election since, the ACT Party has been heavily reliant on their "safe" seat in the Epsom electorate which has launched them into parliament. ${ }^{77}$ In 2008 , the party gained a single electorate seat, and a party vote share of $3.65 \%$; this gave them five seats in Parliament. ${ }^{78}$ In 2011 its share of the party vote dropped significantly, with the party receiving only $1.07 \%$ of the votes cast nationwide. ${ }^{79}$ Despite a tumultuous previous term in the House, it retained its single electorate seat. ${ }^{80}$ The traditionally right-leaning Epsom electorate has been virtually uncontested by the National Party in recent elections. Reports from 2005, 2008 and 2011 indicate that they have focussed only on gaining the party vote from voters in the area. The Party encouraged voters to support the ACT candidate (in 2005 and 2008, Rodney Hide and in 2011, John Banks), so that the one electorate seat exception would be invoked. This encouragement was seen at each election both through the focus of the campaign advertising, and also through the infamous "cup of tea" ${ }^{81}$ The cup of tea "has become a default for New Zealand political leaders to send electoral signals", indicating to voters in strategic electorates where their electorate votes would be best placed. ${ }^{82}$ During the 2011 election campaign,

\footnotetext{
${ }^{74}$ Judith Collins, above n 9.

${ }^{75}$ Judith Collins, above $\mathrm{n} 9$.

${ }^{76}$ Jack Vowles, Peter Aimer, Susan Banducci, Jeffrey Karp \& Raymond Miller Voters Veto: The 2002 Election and the Consolidation of Minority Power (Auckland University Press, Auckland, 2003).

${ }^{77}$ Adam Bennett "Reading the tea leaves in Epsom" (12 Nov 2011) New Zealand Herald $<$ http://nzherald.co.nz $>$.

${ }^{78}$ New Zealand Gazette, above n 59.

${ }^{79}$ See "2011 General Election and Referendum on the Electoral System: Results of the Official Count" (8 December 2011) 190 New Zealand Gazette 5477.

${ }^{80}$ See New Zealand Gazette, above n 79.

${ }^{81}$ See Adam Bennett, above $\mathrm{n} 77$.

${ }^{82}$ Adam Bennett, above $\mathrm{n} 77$.
} 
National Party leader John Key met with John Banks at an Epsom cafe. ${ }^{83}$ Key stated that "if they [Epsom voters] decide to tactically vote and split their vote I wouldn't at all be unhappy", in a clear indication that an electorate vote for Banks would be a good choice. ${ }^{84}$ With ACT Party support dwindling nationwide, it seems likely that their political hopes for 2014 are pinned on similar encouragement being given to Epsom voters in the lead up to that election. ${ }^{85}$ United Future has also benefited from the one electorate seat threshold in past elections through Party Leader Peter Dunne's Ohariu seat, and may also suffer the effects of the abolition of the threshold.

In the most recent polls, the United Future Party and the ACT Party are polling at around one percent. ${ }^{86}$ Each of these polls show the Conservative Party polling at around two percent of the party vote, and thus in a stronger position. Some bloggers and columnists have highlighted this position as showing that the Conservative Party could also benefit from strategic voting at the 2014 Election. Tim Watkin wrote in July 2013 that: ${ }^{87}$

Warkworth is the obvious place for Key to have a cup of tea next year ... Epsom has more than done its duty and Colin Craig could be manoeuvred into the Rodney seat.

If Colin Craig was to win the Rodney seat through strategic voting by the traditionally National-voting electorate, the one electorate seat threshold would allow him to bring in several other MPs, and thus provide the support that the National Party needs to command a majority in the House.

Viable partners in government (whether coalition partners or through confidence and supply agreements) are an extremely important element of the MMP system. Given that, to lose ACT and United Future, as well as the potential for the Conservative Party to enter parliament at 2014, would likely be deeply concerning for the National Party. Such a loss could significantly impact their ability to form a government. This concern has certainly been cited in the online and news media as a key driver for the incumbent government to ignore the recommendations. ${ }^{88}$ On the opposition side, also, partisan self interest is undoubtedly at play.

\footnotetext{
${ }^{83}$ Adam Bennett, above $\mathrm{n} 77$.

${ }^{84}$ Adam Bennett "Political Cups of Tea Shared" (11 Nov 2011) New Zealand Herald <http://nzherald.co.nz>.

${ }^{85}$ See Colmar Brunton, above n 61.

${ }^{86}$ See Colmar Brunton, above n 61.

${ }^{87}$ Tim Watkin "My outlook for 2014: Your guess is as good as mine" (3 July 2013) Pundit $<$ http://www.pundit.co.nz>.

${ }^{88}$ See Andrew Geddis, above n 13; Graeme Edgeler "On Consensus” (15 May 2013) Legal Beagle

$<$ http://www.publicaddress.net $>$; John Armstrong "Naked Self Interest Rules" (15 May 2013) New Zealand
} 
Andrew Geddis, for example, highlights that "part of the reason Labour and the Greens are so supportive of the Commission's recommendations is that they think they will have just this effect on National and its allies." 89

\section{Undermining the Democratic Process}

The term 'democracy' is derived from Greek origins, and literally means "the people rule". 90 In New Zealand, as in other representative democracies, democracy is built upon representation of the people - the people give their consent, through elections, for Parliament to legislate and the government to govern on their behalf. ${ }^{91}$ Representative democracy, however, does not mean that New Zealanders are - or ought to be - satisfied with a system where democracy only exists around election time. While the term democracy eludes a concise definition, New Zealand's constitutional lawyers have attempted to define what it means to be democratic in New Zealand. One such definition that seems to encapsulate the ever-present nature of democracy is that of Margaret Wilson, who states that, "Political decision making is democratic if it enables 'the people' to engage and participate in decisions that affect them in a meaningful way' (emphasis added). ${ }^{92}$

The apparent self-interestness at play in terms of the specific proposed changes indicates that the democratic process is being undermined, as it renders the people's engagement and participation with the review process wholly un-meaningful. The scope of the review was significant in terms of public consultation and expenditure of resources, and thus should have been a meaningful democratic exercise. Andrew Geddis highlighted the way in which the process was run - by "independent, impartial individuals" who received a huge number of public submissions on the issues up for review. ${ }^{93}$ They were tasked with coming up with recommendations "based upon the best evidence the Commission could get on the issues and reflective of the majority sentiments of the thousands of people who took the time and effort" to share their opinions. ${ }^{94}$ In light of this, Geddis came to the conclusion that: ${ }^{95}$

Herald <http://www.nzherald.co.nz>; New Zealand Herald "Collins fails Electoral Review Test” (16 May 2013) New Zealand Herald <http://www.nzherald.co.nz>; Jon Johansson "National Quiet on MMP Changes” (23 April 2013) Dominion Post $<$ http://www.stuff.co.nz $>$.

${ }^{89}$ Andrew Geddis, above $\mathrm{n} 13$.

${ }^{90}$ David Held Models of Democracy (Stanford University Press, California, 2006) at 1.

${ }^{91}$ The Royal Commission on the Electoral System, above n 1, at [1.1].

${ }^{92}$ Margaret Wilson "Constitutional Theory Informed by Practice" in Claire Charters and Dean Knight (ed) We the People(s): Participation in Governance (Victoria University Press, Wellington, 2011) at 183.

${ }^{93}$ Andrew Geddis, above $\mathrm{n} 13$.

${ }^{94}$ Andrew Geddis, above $\mathrm{n} 13$.

95 Andrew Geddis, above n 13. 
... in terms of assessing both what is the public mood regarding MMP's various rules, as well as what is the range of expert opinion on those rules, the Commission is in a far better position than any other body in New Zealand.

This view is particularly persuasive when one considers the nature of the subject up for review in light of the self interest issues. Indeed, Simon Power, the former Minister of Justice charged with setting up the referendum and review process, also publicly expressed this opinion prior to the recommendations being made. In a speech to the 'Reconstituting the Constitution Conference' in 2010, Power highlighted the Government policy (in terms of constitutional and specifically electoral reform) of avoiding "situations where politicians are too heavily involved in the design of any changes." 96 The speech acknowledged that allowing politicians to decide the direction of electoral reform would be akin to "letting panelbeaters design intersections." 97

\section{Democratic Legitimacy}

Discussions around meaningful citizen engagement in the democratic process across the world and in New Zealand stress the importance of 'democratic legitimacy', or conversely, of minimizing "democratic deficiency". Joel Colon-Rios wrote that a constitutional framework must provide opportunities for the exercise of constituent power and "for citizens to participate in constitutional change" in order to be considered legitimate. ${ }^{98}$ In the New Zealand context, he highlighted "obvious problems" in terms of democracy - that constitutional changes can only be made through ordinary legislative processes or through the development of conventions. ${ }^{99}$ In short, Colon-Rios concluded that New Zealanders lack the proper means to exercise their constituent power", ${ }^{100}$ as under the constitutional framework "there is an almost complete identification of 'parliament' and 'people". ${ }^{101}$ Colon-Rios writes that under unwritten constitutions such as New Zealand's and Britain's, "the former appears as a constituent assembly in potentially permanent session, and the latter rarely makes an

\footnotetext{
${ }^{96}$ Simon Power "Speech to Reconstituting the Constitution Conference" (Reconstituting the Constitution Conference, Wellington, 2 September 2010).

${ }^{97}$ Simon Power, above n 96.

98 Joel Colon Rios "New Zealand's Constitutional Crisis" (2011) 24(3) NZULR 449 at pp 455-456.

${ }^{99}$ At 464.

${ }^{100}$ At 467. See also Kalyvas "Popular Sovereignty, Democracy and the Constituent Power" (2005) 12(2) Constellations 223 at pp 226-230, for more discussion around the concept of Constituent Power.

${ }^{101}$ Joel Colon Rios "The Legitimacy of the Juridical: Constituent Power, Democracy, and the Limits of Constitutional Reform" (2010) 48 Osgoode Hall Law Journal 199 at 233.
} 
appearance other than voting in regular elections". ${ }^{102}$ The problem framed by Colon-Rios regarding the New Zealand constitutional framework, and also in a broader context by authors such as Andreas Kalyvas and Vernon Bogdanor, ${ }^{103}$ is further amplified in terms of questions of electoral reform. New Zealanders do not have a means of initiating and meaningfully participating in changes to electoral rules, especially where partisan self interest is at play.

The lack of democratic legitimacy in this area is significant, because electoral rules are fundamental to the operation of democratic elections, and thus are held as lynchpins of the New Zealand constitution. On the fundamental importance of elections, Janine Hayward wrote that: "Under New Zealand's unwritten and non-entrenched constitution ... the triennial election of representatives of the house is arguably the most powerful constitutional check on the Executive". ${ }^{104}$ Likewise, Matthew Palmer writes that: ${ }^{105}$

New Zealand's Constitution affords greater significance to key rules of the representative political process than any of the other of its constitutional rules, at least measured by the formal difficulty of changing them.

The Electoral Act 1993 entrenches a number of provisions found in New Zealand's constitutional statutes. ${ }^{106}$ Under section 268 of the Act, seven provisions relating to the electoral cycle cannot be repealed or amended in the ordinary manner. ${ }^{107}$ These provisions must instead be repealed or amended only where the proposal "is passed by a majority of $75 \%$ of all the members of the House of Representatives" or "has been carried by a majority of valid votes cast at a poll of the electors of the General and Māori electoral districts". The Electoral Commission's recommendations would not alter any of the entrenched provisions, but are still important tweaks to the way that the electoral system operates. It is problematic that such tweaks are determined by political considerations. To some extent, the 1986 Report of the Royal Commission on the Electoral System acknowledged this importance of achieving electoral reform. The Royal Commission highlighted that "the primary way in which the

\footnotetext{
${ }^{102}$ At 233.

${ }^{103}$ See generally Joel Colon Rios, above n 101; Andreas Kalyvas, above n 100; and Vernon Bogdanor The New British Constitution (Oxford: Hart Publishing, 2009).

${ }^{104}$ Janine Hayward, above n 48, at 71.

${ }^{105}$ Matthew Palmer "Open the Doors and Where are the People?" in Claire Charters and Dean Knight (ed) We the People(s): Participation in Governance (Victoria University Press, Wellington, 2011) at 65.

106 Electoral Act 1993, s 268.

${ }^{107}$ Section 268(1).
} 
people give their consent [to the exercise of public power by Parliament and Government] is through elections". 108

The response to the 2012 recommendations of the Electoral Commission is not the only recent example of partisan considerations colouring the forming and reforming of electoral rules. The Electoral Finance Act 2007, introduced by the then Labour Government, was considered by many to be an example of electoral rules being reformed for partisan political gain. The Act amended areas of electoral law to limit third parties' abilities to advertise for political parties around elections and to campaign on political issues. ${ }^{109}$ Although the issues around third party advertising were legitimate non-partisan concerns, the actual legislation passed was largely seen as a knee jerk reaction to members of the Exclusive Brethren funding a significant 'leaflet drop' campaign against the Labour and Green Parties. ${ }^{110}$ It was designed and implemented urgently by the government, apparently to limit the ability of National Party supporters to undertake "parallel campaigning activity". 111 An Editorial in the New Zealand Herald strongly condemned the introduction of the law, asking readers, "When is the Government going to get this message: democracy is not a device to keep the Labour Party in power."112 The proposed law was widely criticised - including by the Law Society and the Human Rights Commission - for "both of its substantive content and of the process by which it was conceived and enacted." 113 The law has since been repealed by the Electoral (Finance Reform and Advanced Voting) Amendment Act 2010, which replaced the rules around electoral advertising with rules that were passed with support from across the House of Representatives, without meaningful democratic participation in the decision. ${ }^{114}$ The passage of the Electoral Finance Act 2007 demonstrated the problem that arises when proposals for electoral reform are left in the hands of those who are elected by such rules. Andrew Geddis wrote that "The normal parliamentary process for considering and enacting law misfired with regards to the Electoral Finance Act." $" 15$ That process again misfired with the response to the Electoral Commission's recommendations on MMP.

\section{E Finding a Solution?}

\footnotetext{
${ }^{108}$ Royal Commission on Electoral Systems, above n 1, at [1.4].

${ }^{109}$ Electoral Finance Act 2007.

${ }^{110}$ Andrew Geddis "The Electoral (finance reform and advance voting) Amendment Bill” (2010) 6(3) Policy Quarterly 3, at 3.

111 At 3.

${ }^{112}$ NZ Herald "Editorial: Democracy under Attack" (12 November 2007) NZ Herald

$<$ http://www.nzherald.co.nz $>$.

113 Andrew Geddis, above n 110, at 3.

${ }^{114}$ Electoral (Finance Reform and Advanced Voting) Amendment Act 2010.

${ }^{115}$ Andrew Geddis, above n 110, at 3.
} 
(a) Introducing 'deliberative' processes

Constitutional theorists have suggested a range of different solutions to the problem posed by states that lack 'democratic legitimacy'. In addressing the shortcomings of representative democracy, an attractive proposition is to introduce 'deliberative" elements to the constitutional framework. 'Deliberative Democracy' is One example of such a solution is Ethan J. Leib's suggestion that a 'deliberative' or 'popular' branch of Government - made up of "randomly selected civil juries" - be established to consider issues that are unsuitable for determination by elected lawmakers. ${ }^{116}$ This idea reflects developments in newly formed democracies, in which popular participation in constitution making has been a key focus. In the specifically New Zealand context, Colon-Rios has suggested a mechanism be created known as the 'Citizen Initiated Constituent Assembly'. ${ }^{117}$ That body would, in essence, allow citizens to propose constitutional change, which would be considered by a specially elected or randomly selected assembly of ordinary citizens to deliberate on the form of the proposal. ${ }^{118}$ The proposed change would then be put to popular vote in a binding referendum. Solutions such as the two outlined would certainly address the issues around political self interest acting as a barrier to constitutional change desired by the public.

As suggested by Leib and Colon-Rios, a mechanism outside of ordinary representative government is desirable in certain situations - such as where self interest has essentially rendered the Electoral Commission's review a 'complete waste of time'. In the specific context of New Zealand electoral laws, the scope of such a mechanism may be much narrower than the proposal of Colon-Rios, which would essentially overhaul the way in which the New Zealand constitution is shaped. It would be possible to address the problematic nature of the lack of citizen engagement in ordinary mechanisms of electoral reform - the 'democratic deficit' - without seriously undermining the power of the New Zealand Parliament to go about its business.

In order to address the problem discussed, the mechanism must enable 'the people' of New Zealand to engage with issues of electoral reform, and to both initiate and participate in the

\footnotetext{
${ }^{116}$ Ethan J Leib Deliberative Democracy in America: a Proposal for a Popular Branch of Government (Pennsylvania State University Press, Pennsylvania, 2005), at pp 9-29.

117 Joel Colon Rios, above n 101, at 468.

${ }^{118}$ At $467-470$.
} 
process of choosing the direction that the electoral system should take. As outlined by the 1986 Royal Commission Report: ${ }^{119}$

The process of choice [of electoral processes] should to the fullest extent possible give each member of the community an equal part in the choice of the Government and a fair opportunity to participate in the process.

\section{Citizens’' Assemblies on Electoral Reform}

It has been suggested by several leading constitutional lawyers that the way in which this could be achieved in New Zealand could be through the use of 'citizens assemblies' for electoral policy-making. ${ }^{120}$ Janine Hayward writes that "Citizens' Assemblies have proven to be useful policy tools overseas in electoral reform", and has suggested that such a tool would have been a preferable way of addressing concerns around New Zealand's electoral processes than the 2011 referendum and subsequent review. ${ }^{121}$ The use of such assemblies is not entirely unprecedented in representative democracies.

Citizens Assemblies on Electoral Reform have been engaged in Canada on two occasions - in British Columbia and Ontario. ${ }^{122}$ On each of these occasions, the Government established assemblies of citizens to consider whether improvements could be made to the current electoral system. $^{123}$ In British Columbia in 2004, an assembly of 160 citizens was chosen almost at random to look at the electoral system, and to consider whether a new model would be preferable. ${ }^{124}$ Like in New Zealand, Canadian processes of electoral reform had, according to Warren and Pearse, been criticized "for being insufficiently inclusive, responsive, or deliberative ... so much that they produce results of questionable legitimacy."125 The assembly thus gave the opportunity for citizens of British Columbia to to be engaged in the electoral reform process. Jonathan Rose, the Chair of the Assembly engaged in Ontario, has supported the use of such assemblies on contentious issues. ${ }^{126}$ He wrote that "Assemblies are

\footnotetext{
${ }^{119}$ Royal Commission on the Electoral System, above n 1, at [1.14].

${ }^{120}$ Janine Hayward, above n 48, at 71; Andrew Geddis, above n 110, at 3.

${ }^{121}$ Janine Hayward, above n 48, at 71.

${ }^{122}$ At 71 .

123 At 71 .

${ }^{124}$ Mark Warren and Hillary Pearse "Introduction: Democratic Renewal and deliberative democracy" in Mark Warren and Hillary Pearse (ed) Designing Deliberative Democracy: The British Columbia Citizens' Assembly (Cambridge University Press, United Kingdom, 2008) at 1.

125 At 4.

${ }^{126}$ Jonathan Rose "Citizens' Assembly a chance to take posturing out of politics" (16 June 2008) NZ Herald $<$ http://www.nzherald.co.nz $>$.
} 
ideal when politicians have a conflict of interest ... Since they have no agenda, their recommendations are viewed as sound ones by stakeholders, politicians and the public."127

The citizens' assembly concept is by no means a perfect democratic institution. The exercises in British Columbia and Ontario showed that the concept does have some inherent weaknesses. Firstly, the randomly selected assemblies were diverse, but were not strictly representative, particularly as involvement was not mandatory, so individuals selected could refuse to participate. ${ }^{128}$ Secondly, the processes were resource intensive - requiring the investment of significant time, money and infrastructure in order to have any success. This is particularly so in terms of the resources required to ensure that the members of the Assembly, ordinary citizens without any expertise in constitutional or electoral laws, would be fully engaged in the issues, some of which were quite complex. ${ }^{129}$ Finally, because the assembly concept required the assemblies' proposals to be put to the public for approval, neither the British Columbian or Ontarian assemblies resulted in any change. In British Columbia the recommended Single Transferable vote (STV) failed to reach 60 percent voter approval, ${ }^{130}$ and in Ontario the proposal to adopt MMP was defeated by the status quo. ${ }^{131}$ The Canadian experiences, however, also showed that the concept is promising. ${ }^{132}$ The assemblies in Ontario and British Columbia demonstrated that "citizens have the capacity to shed their apathy, overcome their ignorance, and reason conscientiously about an unfamiliar and complex political issue. ${ }^{, 133}$ Both of the assemblies had high levels of engagement among the participants, and - especially in the British Columbian case study - were viewed quite favourably by the wider public in terms of their legitimacy. ${ }^{134}$ In spite of its limitations the process would be preferable to the current system of leaving all electoral rule changes up to Members of Parliament. Introducing a 'citizen initiated' mechanism

The Citizens' Assembly model itself addresses concerns about the lack of meaningful involvement of citizens in considering and implementing electoral rule changes. In itself,

\footnotetext{
${ }^{127}$ Jonathan Rose, above n 126.

${ }^{128}$ Mark Warren and Hillary Pearse, above n 124, at 10-11.

129 Janine Hayward, above n 48, at pp 72-73.

${ }^{130}$ Mark Warren and Hilary Pearse, above n 124, at 10-11.

131 Janine Hayward, above n 48, at 71.

132 P Fournier, H van der Kolk, R K Carty, A Blais and J Rose When Citizens Decide: lessons from citizens' assemblies on electoral reform (Oxford University Press, United Kingdom, 2011) at 155.

${ }^{133}$ At 150

${ }^{134}$ Janine Hayward, above n 48, at pp 72-73.
} 
however, it does not address the problem that citizens also cannot initiate changes. Drawing on the model proposed by Colon-Rios - which would allow citizens to initiate constitutional changes - the Citizens' Assembly model could be similarly extended. Under the extended model, a proposal for a Citizens' Assembly on Electoral Reform would be triggered either by a majority vote in the House of Representatives, or initiated by citizen(s) collecting a required number of signatures from registered electors, as is required by the Citizen Initiated Referenda process, which requires a petition be signed at least ten percent of registered electors. $^{135}$

While the Citizen Initiated Referenda - whereby a petition signed by ten percent of electors can force a non-binding referendum to be held on the petition question - is a widely criticized process, ${ }^{136}$ much of the criticism around a citizen initiated mechanism would not carry so much weight in terms of a 'citizen initiated citizens' assembly' process. In terms of its' major weaknesses, Fenton and Geddis write that the process is marred by leading questions and poor drafting - the result of very few restrictions on the way the question must be framed. ${ }^{137}$ This undermines the usefulness of the exercise, because the results may not accurately reflect the gravity of the issue. A citizens' assembly would address concerns about questions, because the scope of an assembly is to deliberate on the issue at hand, rather than being limited to a yes or no question. The nature of the assembly means that the referendum question that is produced is much more likely to be a neutral and well-reasoned question on technical changes to the operation of the electoral system, rather than an emotionally or morally charged question on policy. Essentially, while "in general ... referendums are blunt and crude devices" ${ }^{\prime 138}$, the citizen initiated citizens' assemblies would be much more targetted forms of democratic engagement.

The other major concern around Citizen Initiated Referenda is the non-binding nature of the process. ${ }^{139}$ Even a decisive "yes" or "no" vote does not compel any legislative action, and so is often considered a waste of time. ${ }^{140}$ While a citizens' assembly may also result in no legislative action, for example if the assembly was to recommend - after deliberating on the issue at hand - that no change be put to the public, or if - as occurred in British Columbia and

\footnotetext{
${ }^{135}$ Citizen Initiated Referenda Act 1993.

${ }^{136}$ Bridget Fenton and Andrew Geddis "Citizen Initiated Referenda" (October 2009) New Zealand Law Journal 334 at 334.

${ }^{137}$ At 334-336.

${ }^{138}$ The Royal Commission on Electoral Systems, above n 1, at [7.30].

${ }^{139}$ Bridget Fenton and Andrew Geddis, above n 136, at 335.

${ }^{140}$ At 335 .
} 
Ontario - the proposal of the assembly failed to gain sufficient support at the subsequent referendum, the result would be binding should a change be proposed that was carried at referendum. Furthermore, learning from the experiences in other jurisdictions, constitutional lawyers have suggested that the assembly process could be tweaked in order to give the public more information on the assembly, thus improving its' legitimacy - and the likelihood the public will support its deliberations. ${ }^{141}$ Fournier et al. suggest, for example, that the assemblies should have a more significant public profile, and "their members should be actively involved in the debate", working "to educate the population about their reasoning and decisions". ${ }^{142}$

In their study of experiences with Citizens' Assemblies in Canada and the Netherlands, Fournier et al emphasised that such assemblies "ought to be used sparingly under exceptional circumstances" - largely due to the resource intensive nature of such assemblies. ${ }^{143}$ They considered occasions where elected legislators failed to implement change that voters supported to be the "optimal circumstances for creating a citizens' assembly."144 The 'citizen initiated' mechanism would allow the citizens' assembly process to work as a backstop where the ordinary law making situation fails to produce a satisfactory result. If, as with the Electoral Commission's recommendations, a proposed change to electoral rules is either made or not made for what appears to be political reasons, there would be recourse for the voting public to force the issue to be considered in a non-partisan forum. A 'citizen initiated' citizens' assembly process for addressing questions of electoral rule changes would address many of the issues raised regarding partisan self interest and a lack of democratic involvement with the electoral rule making process.

\section{Conclusion}

The 2012 Report of the Electoral Commission on the Review of the MMP system recommended that several changes be made to the way in which future parliaments are elected in New Zealand. Its foremost recommendations were to lower the five percent party vote threshold for entry into Parliament to four percent, and to abolish the one electorate seat exception to that rule. While those changes would not fundamentally change the way in

\footnotetext{
${ }^{141}$ Janine Hayward, above n 48, at 73; P Fournier et al, above n 132, at 156.

${ }^{142}$ Fournier et al, above n 132, at 156.

${ }^{143}$ At 155.

144 At 155.
} 
which elections operate, they would certainly have some effect on the make up of future Parliaments and on voting behaviour in key electorates around the country.

The lack of legislative response to the recommendations highlights an issue inherent in New Zealand's constitutional arrangements. The official response to the report was that no legislative action could be taken on the Electoral Commission's recommendations because there was no consensus across the House of Representatives as to what changes should be adopted. This response is almost entirely artificial, as there is little evidence that a consensus is required to make such a change and, furthermore, the nature of the topic for review virtually ensures that political parties will disagree. The problem is thus: while electoral rules are fundamental to the legitimacy of the democratic process, the 'unwritten' constitution provides that electoral reforms (other than those entrenched in section 268 of the Electoral Act 1993) are entirely decided by the elected legislature. This arrangement is problematic, because this leaves those who are elected by rules to decide what the rules should or should not be, and consequently gives rise to issues of partisan self interest. Studies of electoral reform processes around the world have shown that due to self interest, political parties tend to support the process that is most likely to favour their chances in upcoming elections. Generally, with the exception of the New Zealand First Party's position, this conclusion is mirrored in the positions of each New Zealand political party.

This inherent issue in our constitutional arrangements is that there is a lack of democratic legitimacy - a democratic deficit - in terms of electoral reform processes. Citizens are unable to initiate and participate in electoral rule changes, which are instead made through ordinary parliamentary processes, coloured by partisan self interest.

The solution proposed in this paper, a 'citizen initiated' form of citizens assembly, draws on the ideas of various constitutional lawyers and theorists such as Joel Colon-Rios and Andrew Geddis, as well as the largely positive experience of citizens' assemblies on electoral reform in Canada. The process briefly outlined would address the issue of self interest colouring the electoral reform process, and give citizens a meaningful way to initiate and participate in important decisions relating to the democratic process where they see that the ordinary lawmaking process has failed to achieve a satisfactory result. 
VI Bibliography

ALegislation

1 New Zealand

Citizen Initiated Referenda Act 1993.

Constitution Act 1986.

Electoral Act 1993.

Electoral Finance Act 2007.

Electoral (Finance Reform and Advanced Voting) Amendment Act 2010.

Electoral Referendum Act 2010.

New Zealand Bill of Rights Act 1990.

\section{Germany}

Bundewahlgesetz (Federal Election Law) 1956 (Germany).

\section{BBooks}

Vernon Bogdanor The New British Constitution (Oxford: Hart Publishing, 2009).

Jonathan Boston New Zealand Under MMP: A New Politics? (Auckland University Press, Auckland, 1996).

David Held Models of Democracy (Stanford University Press, California, 2006).

Shaun Donovan and Todd Donovan The Limits of Electoral Reform (Oxford University Press, USA, 2013).

P Fournier, H Van der Kolk, RK Carty, A Blais and J Rose When Citizens Decide: lessons from citizens' assemblies on electoral reform (Oxford University Press, Oxford, 2011).

Sir Ivor Jennings The Law and the Constitution $\left(5^{\text {th }}\right.$ ed, University of London Press, 1959).

Philip A Joseph, Constitutional and Administrative Law in New Zealand (2nd ed, Brookers, 2001).

Ethan J Leib Deliberative Democracy in America: a Proposal for a Popular Branch of Government (Pennsylvania State University Press, Pennsylvania, 2005).

Ryan Malone Rebalancing the Constitution: The Challenge of Government Law-Making under MMP (Institute of Policy Studies, Wellington, 2008) . 
Raymond Miller NZ Government and Politics (4th Ed, Auckland, Oxford University Press, 2006).

Raymond Miller NZ Government and Politics (5th Ed, Auckland, Oxford University Press, 2010).

Geoffrey Palmer and Matthew Palmer Bridled Power (4th Ed, Melbourne, Oxford University Press, 2004).

Geoffrey Palmer and Matthew Palmer Bridled Power (3rd Ed, Auckland, Oxford University Press, 1997).

Jack Vowles, Peter Aimer, Susan Banducci, Jeffrey Karp \& Raymond Miller Voters Veto: The 2002 Election and the Consolidation of Minority Power (Auckland University Press, Auckland, 2003).

John Vowles, Peter Aimer \& Helena Catt Towards Consensus?: The 1993 Election and Referendum in New Zealand and the Transition to Proportional Representation (Auckland, Auckland University Press, 1995).

C Chapters in Books

Alan McRobie "The Electoral System” in Phillip Joseph (ed) Essays on the Constitution (Brookers Ltd, Wellington, 1995).

Matthew Palmer "Open the Doors and Where are the People?" in Claire Charters and Dean Knight (ed) We the People(s): Participation in Governance (Victoria University Press, Wellington, 2011).

Mark Warren and Hillary Pearse "Introduction: Democratic Renewal and deliberative democracy" in Mark Warren and Hillary Pearse (ed) Designing Deliberative Democracy: The British Columbia Citizens' Assembly (Cambridge University Press, United Kingdom, 2008). Margaret Wilson "Constitutional Theory Informed by Practice" in Claire Charters and Dean Knight (ed) We the People(s): Participation in Governance (Victoria University Press, Wellington, 2011).

Jean Jacques Rousseau "The Social Compact" in The Social Contract (France, 1762).

Constitutional Theory Informed by Practice" in Claire Charters and Dean Knight (ed) We the People(s): Participation in Governance (Victoria University Press, Wellington, 2011).

D Journal Articles 
Carles Boix "Setting the Rules of the Game: The Choice of Electoral Systems in Advanced Democracies" (1999) 93(3) American Political Science Review 609.

Shaun Bowler, Todd Donovan, and Jeffrey A. Karp "Why Politicians Like Electoral Institutions: Self-interest, Values or Ideology?” (2006) 68(2) Journal of Politics 434.

Joel Colon Rios “New Zealand's Constitutional Crisis” (2011) 24(3) NZULR 449.

Joel Colon Rios "The Legitimacy of the Juridical: Constituent Power, Democracy, and the Limits of Constitutional Reform” (2010) 48 Osgoode Hall Law Journal 199.

Bridget Fenton and Andrew Geddis "Citizen Initiated Referenda" (October 2009) New

Zealand Law Journal 334.

Andrew Geddis “The Legal Status of Political Parties Under MMP” (2009) 7(1) New Zealand Journal of Public and International Law 21.

Janine Hayward "Citizens Assemblies and Policy Reform in New Zealand" (2013) 9(2) Policy Quarterly 70.

Andreas Kalyvas "Popular Sovereignty, Democracy and the Constituent Power" (2005) 12(2) Constellations 223.

Andreas Kalyvas “The Basic Norm and Democracy in Hans Kelsen's Legal and Political Theory (2006) 32 Philosophy and Social Criticism 573.

Geoffrey Palmer “A Bill of Rights for New Zealand: A White Paper” [1984-1985] 1 AJHR A6.

Matthew Palmer "New Zealand Constitutional Culture” (2007) 22 NZULR 565.

Jean-Benoit Pilet \& Damien Bol "Party Preferences and Electoral Reform: How Time in Government Affects the Likelihood of Supporting Electoral Change" (2013) 34(3) West European Politics 568.

Jonathan Rose "Putting the Public back in Public Policy: the Ontario citizens' assembly on electoral reform (2007) 30(3) Canadian Parliamentary Review 9.

Kenneth Sheppsle "A Comment on Insitutional Change" (2001) 13 Journal of Theoretical Politics 321.

John Wallace "Reflections on Constitutional and Other Issues Concerning our Electoral System: The Past and the Future" (2002) 33 VUWLR 719.

\section{EParliamentary Debates}

(21 August 1990) 510 NZPD 3761.

(14 October 2003) 612 NZPD 9096.

(1 December 2004) 622 NZPD 17332. 
(18 December 2007) 644 NZPD 14038.

(8 December 2010) 669 NZPD 15961.

(15 December 2010) 669 NZPD 16441.

FParliamentary and Government Materials

"2008 General Election: Results of the Official Count" (22 November 2008) 180 New Zealand Gazette 4638.

"2011 General Election and Referendum on the Electoral System: Results of the Official Count" (8 December 2011) 190 New Zealand Gazette 5477.

Confidence and Supply Agreement with Act New Zealand (5 December 2011) New Zealand Government $<$ www.parliament.govt.nz $>$.

Relationship Accord and Confidence and Supply Agreement with the Māori Party (11 December 2011) New Zealand Government <www.parliament.govt.nz>.

Confidence and Support Agreement with United Future New Zealand (5 December 2011)

New Zealand Government <www.parliament.govt.nz>.

Kenneth Keith "On the Constitution of New Zealand: An Introduction to the Foundations of the Current Form of Government" in Cabinet Office (ed) The Cabinet Manual 2008.

Geports

Electoral Commission Report of the Electoral Commission on the Review of the MMP Voting System (E9, 29 October 2012).

The Royal Commission on the Electoral System Towards a Better Democracy (Government Printer, December 1986).

H Internet Resources

John Armstrong "Naked Self Interest Rules" (15 May 2013) New Zealand Herald $<$ http://www.nzherald.co.nz $>$.

Adam Bennett "Reading the tea leaves in Epsom" (12 Nov 2011) New Zealand Herald $<$ http://nzherald.co.nz $>$.

Adam Bennett "Political Cups of Tea Shared" (11 Nov 2011) New Zealand Herald $<$ http://nzherald.co.nz $>$. 
Kate Chapman "Government's MMP review response slammed” (15 May 2013) Stuff Politics $<$ http://www.stuff.co.nz>.

Judith Collins "MMP Changes Impossible Without Agreement" 15 May 2013 $<$ http://www.beehive.govt.nz>.

Colmar Brunton "Current ONE New Colmar Brunton Poll” (25 Aug 2013) Colmar Brunton New Zealand <http://www.colmarbrunton.co.nz $>$.

Lianne Dalziel “Minister's response to MMP review a travesty (14 May 2013) Labour Party $<$ http://www.labour.org.nz>.

Graeme Edgeler “On Consensus” (15 May 2013) Legal Beagle $<$ http://www.publicaddress.net $>$.

Andrew Geddis “Stop Wasting our Time” (14 May 2013) Pundit <http://pundit.co.nz>.

Jon Johansson "National Quiet on MMP Changes" (23 April 2013) Dominion Post $<$ http://www.stuff.co.nz>.

New Zealand Herald "Collins fails Electoral Review Test” (16 May 2013) New Zealand Herald $<$ http://www.nzherald.co.nz $>$.

New Zealand Herald "Editorial: Democracy under Attack" (12 November 2007) NZ Herald $<$ http://www.nzherald.co.nz>.

Simon Power "Bill for referendum on voting systems passed unanimously" (15 December 2010) New Zealand Government <http://beehive.govt.nz>.

Jonathan Rose "Citizens' Assembly a chance to take posturing out of politics" (16 June 2008) NZ Herald <http://www.nzherald.co.nz>.

Vernon Sharp "MMP Proposals need Referendum" (16 May 2013) Stuff $<$ http://www.stuff.co.nz>.

New Zealand Government "Party Positions on MMP" (15 May 2013) $<$ http://www.beehive.govt.nz $>$.

Holly Walker "Govt Playing Politics with our Electoral System” (14 May 2013) Green Party of Aotearoa $<\mathrm{http}: / /$ www.greens.org.nz $>$.

Tim Watkin "My outlook for 2014: Your guess is as good as mine" (3 July 2013) Pundit $<$ http://www.pundit.co.nz>.

\section{Other Resources}

Simon Power, Speech to Reconstituting the Constitution, 2 September 2010. 
The word count of this paper is approximately 7666 words, excluding cover, contents, abstract, footnotes and bibliography. 